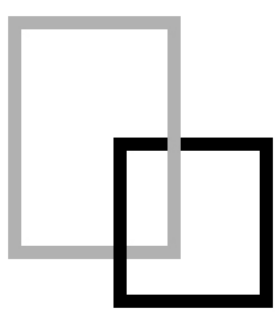

\title{
ZAGADNIENIE OCHRONY MIEJSC PAMIĘCI W TEORII I W PRAKTYCE
}

Protection of places of memory as a theoretical and practical issue

\section{Wojciech Kowalski*}

SUMMARY: As a result of analyse of chosen national and international legal acts author came to conclusion that no definition specifying places of memory as objects of legal protection had yet been adopted in these regulations. However this in no way means that places of memory remain completely outside legal area, although they are covered by the legal system of heritage protection merely within the framework of general definition of heritage. In particular, author argues that places of memory can be protected under 1972 UNESCO World Heritage Convention as definition of heritage (art. 1) encompasses "historical value” criterion in relation to all elements of this heritage, namely to monuments, groups of buildings and sites. Such thesis is strongly supported by practical application of criterion VI of Operational Guidelines by World Heritage Committee. Almost all monuments and sites inscribed on the World Heritage List under this criterion are to maintain memory of important events, beliefs, ideas etc. Intangible component was therefore a basis of these inscriptions although presence of material component as "a witness" was also important. It is however specially interesting to note that the Auschwitz Birkenau German Nazi Concentration Camp (1940-1945) was inscribed as the only one symbol of Holocaust what was underlined by the condition that no other such monuments would be inscribed in the future. It seems clear that by this fact the new principle of "symbolic representation" was adopted by Committee. The problem is that such principle has no legal basis, in particular it cannot be found in the 1972 Convention and for this reason decision establishing it is not binding for future inscriptions.

KEYWORDS: place of memory, legal definition, UNESCO 1972 Convention, Criterion VI of Operational Guidelines

Współcześnie nie podlega już raczej dyskusji wzrastające znaczenie miejsc pamięci i ich rola jako bardzo ważnego elementu dziedzictwa kulturowego. Mają one zwykle znaczenie lokalne, ale często także znacznie szersze, na przykład, niejednokrotnie budując tożsamość narodową. Są wreszcie i takie, których doniosłość przekracza granice państw i są one istotne dla całej ludzkości stając się w ten sposób częścią wspólnego, światowego dziedzictwa kulturowego. Mając na uwadze te okoliczności pojawia się naturalne pytanie, czy miejsca pamięci znalazły stosowne do swego znaczenia miejsce w regulacjach prawnych, a jeżeli tak, to czy są one ewentualnie wystarczające. Podobnie ważną kwestiąjest stosowanie tych regulacji w praktyce. Aby odpowiedzieć na te pytania artykuł rozpocznie zarysowanie istoty koncepcji takich miejsc, po czym można będzie dokonać krótkiego przeglądu aktualnego stanu ustawodawstwa wybranych krajów oraz dokumentów i stosowania prawa międzynarodowego. Analiza ta pozwoli na sformułowanie nasuwających się

* Wojciech Kowalski, University of Silesia in Katowice

https://orcid.org/0000-0001-6532-9796 
wniosków.

Już na wstępie należy podkreślić, że miejsca pamięci nie doczekały się jeszcze ani ogólnie przyjętej definicji „encyklopedycznej”, ani tym bardziej prawnej. Z analiz pioniera badań nad tym zagadnieniem, P. Nory, wynika, że mogą to być miejsca w dosłownym rozumieniu tego słowa, z którymi określone społeczności, takie jak na przykład, naród, czy grupa etniczna, łączą swoje wspomnienia i uważają je za nieodłączną część swojej tożsamości ${ }^{1}$. Chodzi o miejsca, jak dodaje, w których pamięć się krystalizuje i „ukrywa”, gdzie „wyczerpujący kapitał wspólnej pamięci się kondensuje i jest wyrażony"', przez co w wyniku działania człowieka lub czasu stały się one symbolicznym elementem dziedzictwa jakiejkolwiek wspólnoty ${ }^{3}$. Tak rozumiane pojęcie miejsca pamięci przyjęło się początkowo we francuskiej, a potem i międzynarodowej literaturze, a obecnie określające je terminy lieu de memoire, place of memory lub site of memory weszły także do języka potocznego oraz praktyki ${ }^{4}$. Czy wobec wskazanego wyżej wzrastającego znaczenia znalazło ono także swoje odzwierciedlenie w regulacjach prawnych?

Już na wstępie tej analizy należy najogólniej stwierdzić, że da się w omawianej materii zauważyć dwie techniki legislacyjne, które można dla potrzeb niniejszego artykułu nazwać podejściem europejskim i angloamerykańskim. Zacznijmy od kilku przykładów pierwszego $\mathrm{z}$ nich, poczynając od prawa niemieckiego. $\mathrm{W}$ ustawach przyjętych w poszczególnych landach ${ }^{5}$ przedmiot ochrony określony jest zwykle bardzo syntetycznie i ogólnie. Wskazuje się przede wszystkim, obiekty materialne, na przykład, budowle itp., stanowiące „część dziedzictwa kulturowego", które chronione są „z powodu ich .... wartości”, czy też „ich znaczenia”. Można jednak również znaleźć bardziej rozbudowane kryteria, które wskazują na przykład, że zabytkiem w sensie prawnym jest rzecz, której określona wartość, w tym na przykład, historyczna

1 Nora : Mémoire collective, w: J. Le Goff, P. Nora (red) : Faire de l'histoire. Gallimard, Paris 1974, s. 401, por, także A. Szpociński: Miejsca pamięci (lieux de memoire). w: Teksty Drugie, nr 4, 2008, s. 12.

2 “(...) places of memory or lieux de mémoire refer to those places where „memory crystallizes and secrets itself (...)". http://memory.irf-network.org/.

3 „A lieu de mémoire is any significant entity, whether material or non-material in nature, which by dint of human will or the work of time has become a symbolic element of the memorial heritage of any community (...)". P. Nora: From lieux de mémoire to realms of memory. W: P. Nora, L. D. Kritzman: Realms of memory: Traditions. Columbia Univ. Press, New York,1996.

4 Tytułem przykładu wystarczy podać stronę Historic England: Sites of memory: Black British History in the 18th and 19th Centuries. Czytamy na niej, że "we uncover the history of black people during the 18th and 19th centuries by exploring the stories behind our local streets, buildings and landmarks" poniewaz "it is difficult to research the lives of black people from the official records alone". Ps://www.historicengland.org.uk/research/ inclusive-hritage/the-slave-trade-and-abolition/sites-of-memory: Black British History in the 18th and 19th Centuries I Historic England, odczyt 16 marca 2018 r.

5 W Niemczech problematyka ochrony dziedzictwa kulturowego regulowana jest na poziomie legislatur krajowych (Landów), a tradycja ta sięga dekretu Ludwika I, Wielkiego Księcia Hesji z 1818 roku, por., M. Hunter: The Preconditions of Preservation: A Historical Perspective. W: D. Loventhal, M. Binney (Eds): Our past before us. Why do we save it? London 1981, str. 24.

6 H. G. Watzke, J. Cramer, P. v. Kodolitsch: Federal Republic of Germany: W: Protection and cultural animation of monuments, sites, and historic towns in Europe. German Commission for UNESCO, Bonn 1980, str. 139. 


\section{Zagadnienie ochrony miejsc pamięci w teorii i w praktyce}

powodują poddanie jej szczególnej ochronie ${ }^{7}$. Czasem znajdujemy dodatkowe określenia, na przykład, w ustawie przyjętej w Badenii - Wirtembergii z 1971 roku czytamy, że zabytek to „obiekt lub zbiór obiektów i część obiektów, ochrona których leży w interesie publicznym z powodów”, między innymi, „historii lokalnej” (art. 2)8. Ponieważ prawa krajowe funkcjonują jako uzupełnienie federalnych ustaw podstawowych należy jeszcze zwrócić uwagę na prawo regulujące procedury budowlane ${ }^{9}$ oraz zagadnienie odnowy i rozwoju miast ${ }^{10}$. Szczególne znaczenie ma tu nowelizacja prawa budowlanego dokonana w 1976 roku $^{11}$, w której zwrócono specjalną uwagę na ochronę dziedzictwa kulturowego ośrodków miejskich. Podkreślono w niej, że plany „winny uwzględniać przestrzenie, zabudowę, ulice i place o doniosłości historycznej, artystycznej lub architektonicznej, warte ochrony". W tak określonych przez prawo federalne ramach ogólnych władze danego landu stosują dopiero swoje przepisy krajowe o ochronie dziedzictwa kulturowego ${ }^{12}$.

Pokazując ramy prawne ochrony dziedzictwa należy jeszcze zwrócić uwagę, iż na poziomie landów przyjęto równolegle specjalne ustawy poświęcone ochronie miejsc pamięci związanych z ostatnią wojną. Wynika to z ogólnej polityki Niemiec, polegającej na przyjęciu przez ten kraj specjalnej odpowiedzialności za ofiary reżimu hitlerowskiego i konsekwencje drugiej wojny światowej. Wyrazem tego jest, między innymi, obowiązek zachowania żywej pamięci o tych, którzy ucierpieli pod rządami III Rzeszy. Z tego też powodu Rząd RFN wspiera funkcjonowanie wielu muzeów, miejsc pamięci o znaczeniu narodowym. Ogólnie pojęcie to wyjaśnia H. Schulze jako ,długowieczne, trwające przez pokolenia punkty krystalizowania się zbiorowej pamięci i tożsamości"13. Aktualną koncepcję realizacji tej polityki na poziomie federalnym prezentuje dokument opracowany przez Urząd ds. Kultury i Mediów i przedstawiony w Bundestagu w 2008 roku $^{14}$. Wyjaśniono w nim, że polega ona na ustanowieniu i utrzymaniu miejsc pamięci

7 Uogólnienie J. Pruszyńskiego, tegoż: Ochrona prawna zabytków w Republice Federalnej Niemiec. Teksty $i$ komentarze. Warszawa 1992, str. 17.

8 Th. Adlercreutz: Four issues of Cultural Heritage Law in six European countries. Central Board of National Antiquities. National Historical Museums. Sweden. Stockholm 1993, str. 11-12, por., także podobne sformułowanie art. 1 ust. 1 ustawy bawarskiej z 25 czerwca 1973 roku, Denkmalpflege Informationen. The Bavarian State Conservation Office. Protection and Preservation of Historic Buildings and Archeological Sites in Bavaria. München 1987, str. 21.

9 Bundesbaugesetz vom 27. Juni 1960, Bundesgesetzblatt 1960, I, str. 341 et seq., tekst jednolity Bundesgesetzblatt 2004, I, str. 2414 et seq.

10 Städtebauförderungsgesetz vom 27. Juli 1971, Bundesgesetzblatt 1971, I, str. 1125 et seq.

11 Bundesbaugesetz 1976, Bundesgesetzblatt 1976, I, str. 2221 et seq.

12 Relację pomiędzy prawem federalnym a krajowymi w opisywanym zakresie szczegółowo wyjaśniają $\mathrm{H}$. -G. Watzke, J. Cramer, P. v. Kodolitsch, op. cit., str. 137 et seq. Por, także opis funkcjonowania tych regulacji na przykładzie renowacji konkretnych miast, Celle, str. 155 et seq., Ladenburg, str.165 et seq., Nuremberg, str. 177 i Regensburg, str. 187 et seq.

13 L. Kończyk, Pedagogika (miejsc) pamięci, w: Ogrody Nauk i Sztuk: Debiuty 2012, red. A. Kobylarek, A .Gil, L. Kołodziejczak, Wrocław 2012, s. 124-125.

14 Fortschreibung der Gedenkstättenkonzeption des Bundes. Verantwortung wahrnehmen, Aufarbeitung verstärken, Gedenken vertiefen. Deutscher Bundestag, Drucksache 16/9875. 
w Niemczech, które poświęcone będą przede wszystkim upamiętnieniu ofiar dwóch systemów totalitarnych, narodowego socjalizmu i dyktatury komunistycznej (w dawnej NRD) ${ }^{15}$. Przykładem takiego aktu jest ustawa przyjęta w landzie Saksonia ${ }^{16}$. Wskazano w niej konkretne miejsca pamięci objęte regulacją, a są to zgodnie z $\$ 3$ ustawy synagogi w Dreźnie i Görlitz oraz miejsca dawnych synagog w Kamienicy Saskiej i Lipsku, a nadto dawne obozy koncentracyjne i ich podobozy; miejsca pamięci ofiar politycznych reżimów; mogiły ofiar wojen ${ }^{17}$.

Drugim prawem szczególnie interesującym ostatnio dla czytelnika polskiego w omawianym kontekście jest prawo austriackie. W art. 1 ust. 1 ustawy o ochronie zabytków z 1923 roku $^{18}$ wyjaśniono, że przepisy tego aktu stosuje się do "ruchomych i nieruchomych przedmiotów stworzonych przez człowieka" (...), które mają znaczenie historyczne (...) lub inne znaczenie kulturowe, jeżeli, z powodu tego znaczenia ich ochrona leży w interesie publicznym. Zgodnie zaś z ust. 2 tego przepisu dla rozumienia tego interesu podstawowe znaczenie ma to czy i w jakim stopniu dany zabytek stanowi świadectwo historyczne. W ramach tego kryterium wskazany przepis jest podstawą ochrony miejsc pamięci, przy czym w myśl interpretacji Austriackiej Akademii Nauk, ogólnie definiuje się je jako te miejsca, zarówno topograficzne jak i metaforyczne, którym dana wspólnota nadała funkcję wspólnej pamięci ${ }^{19}$. Przykładem takiego miejsca jest od 1949 roku dawny obóz koncentracyjny Mauthausen chroniony pod nazwą „Miejsce Pamięci Mauthausen”.

W relatywnie nowym francuskim kodeksie dziedzictwa z 2005 roku $^{20}$ znajdujemy także syntetyczną definicję, która określa zabytki jako „zespół dóbr, nieruchomych i ruchomych, zarówno publicznych jak i prywatnych, które posiadają wartość z punktu widzenia historii, sztuki, archeologii, estetyki, nauki lub techniki”21. Brak jest natomiast jest aktu prawnego,

15 M. Zaborski: Monuments and memorial sites in Poland and Germany. W: K. Ziemr (red): Memory and Politics of Cultural Heritage in Poland and Germany. Warszawa 2015, str. 83 et seq.

16 Sächsisches Gesetz über Versammlungen und Aufzüge (Das Gesetz über Versammlungen und Aufzüge (Versammlungsgegetz) in der Fassung der Bekanntmachung vom 15. November 1978 (BGBI. I S. 1789), zuletzt geändert durch Artikel 1 des Gesetzes vom. 24 März 2005 (BGBI. I S. 969), gilt mit Ausnahme von $\$ 15$ Abs. 2 mit den nachfolgenden Ergänzungen als Landesrecht fort.

17 M. Zaborski, op. cit., str. 88.

18 Bundesgesetz betreffend den Schutz von Denkmalen wegen ihrer geschichtl, künstlerischen oder sonstigen kulturellen Bedeutung, BGBl. Nr. 533/1923, ostatnia nowelizacja BGBl. I Nr. 92/2013.

19 'Places of Memory' are generally defined as those locations - both topographical and metaphorical - which are assigned a collective, memory function' by a given community. The relationship between memory and identity forms the awareness framework. The representation of memory is analyzed in various areas of social interaction, e.g. the memory function of signs and symbols in public spaces, or of narratives in which the concepts of ,ourselves' and ,others' are defined. A main area of research is devoted to the debate on the ethical ,memory commandment' [i.e. , thou shall not forget'] still prevalent in cultural memory with regard to Nazi crimes." https://www.oeaw.ac.at/en/austrian-academy-of-sciences.

20 Code du patrimoine. Ordonnance no 2005 - 1128 du 8 septembre 2005, Legifrance.gouv.fr.

21 La parimoine sentend, au sens du présent code, de l'ensemble des bies, immobilieurs ou mobiliers, relevant de la propriété publique ou privé, qui présentent un intérêt historique, artistique, archéologique, estétique, scintifique ou technique (art. L1 kodeksu). 


\section{Zagadnienie ochrony miejsc pamięci w teorii i w praktyce}

który zawierałby precyzyjniejszą definicję legalną miejsc pamięci, które wobec tego należy kwalifikować jako zabytki chronione ze względów historycznych. Analizowane pojęcie funkcjonuje zaś w praktyce, na przykład, Ministerstwo Obrony Republiki Francuskiej proponuje „Ścieżki Pamięci” („Chemins de Mémoire”), w ramach których ujęto wykaz miejsc pamięci narodowej, począwszy od 1870 r. Definicja miejsc pamięci podana została przez Commission for the Compensation of Victims of Spoliation, gdzie wyjaśniono, iż „łączy ono koncept historyczny z fizycznym ucieleśnieniem, zabytek, miejsce lub symbol, realny lub idealny, który uczestniczy w konstytuowaniu się wspólnej pamięci”'22. Po definicji wskazane są niektóre z miejsc pamięci narodowej, w tym kilka dawnych niemieckich obozów koncentracyjnych, na przykład, The Memorial of Vernet-d'Ariège Internment Camp, Montluc Prison National Memorial w Lyonie, czy Site of the Former Natzweiler-Struthof Camp itp.

Ostatnim przykładem koncepcji europejskiej jest prawo polskie, które również opiera się na ogólnej definicji zabytku, rozumianego jako „nieruchomość lub rzecz ruchomą, ich części lub zespoły, będące dziełem człowieka lub związane z jego działalnością i stanowiące świadectwo minionej epoki bądź zdarzenia, których zachowanie leży w interesie społecznym ze względu na posiadaną wartość historyczną, (...)"23. Równolegle do tej regulacji istnieje jeszcze specjalna ustawa o ochronie terenów byłych hitlerowskich obozów zagłady z 1999 roku, która poddaje ochronie jako „pomniki zagłady” wskazane w niej niebezpośrednio obiekty związane z tą zagładą, w tym Pomnik Męczeństwa w Oświęcimiu, Pomnik Męczeństwa na Majdanku, Muzeum „Stutthof” w Sztutowie, Muzeum Gross-Rosen w Rogoźnicy, Mauzoleum Walki i Męczeństwa w Treblince, Muzeum Martyrologiczne - Obóz w Chełmnie nad Nerem, Muzeum Byłego Obozu Zagłady w Sobiborze oraz Były Obóz Zagłady w Bełżcu ${ }^{24}$. Dla pełnego obrazu ochrony miejsc pamięci w Polsce należy jeszcze wspomnieć o ustawie o Instytucie Pamięci Narodowej - Komisji Ścigania Zbrodni przeciwko Narodowi Polskiemu ${ }^{25}$, na mocy której instytucja ta prowadzi działalność związaną z upamiętnianiem historycznych wydarzeń, miejsc oraz postaci w dziejach walk i męczeństwa Narodu Polskiego, zarówno w kraju, jak i za granicą, a także miejsc walk i męczeństwa innych narodów na terytorium Rzeczypospolitej Polskiej,

22 "Place of memory” combines historical concepts and physical manifestations: a monument, a place or a symbol, concrete or ideal, which participates in the constitution of collective identity. Some of them reflect significant events of the past, often occurring in a dramatic context, of which the community wanted to preserve the memory. Commission pour l'Idemnification des Victimes de Spoliations, http://www.civs.gouv.fr.

23 Art. 3 pkt 1 ustawy o ochronie zabytków i opiece nad zabytkami z dnia 23 lipca 2003 roku. DU 2003, nr 162, poz. 1568.

24 Art. 2 ustawy z dnia 7 maja 1999 r. o ochronie terenów byłych hitlerowskich obozów zagłady. DU 2015, poz. 2120.

25 Ustawa z dnia 18 grudnia 1998 r. o Instytucie Pamięci Narodowej - Komisji Ścigania Zbrodni przeciwko Narodowi Polskiemu, DU 2016, poz. 152. 
w okresie od dnia 8 listopada 1917 r. do dnia 31 lipca 1990 r. (art. 1 pkt 6) ${ }^{26}$.

Drugie podejście do ochrony miejsc pamięci reprezentuje prawo angielskie i amerykańskie. $\mathrm{W}$ pierwszym $\mathrm{z}$ nich nie istnieje definicja legalna miejsc pamięci, ale prawo wskazuje jednak bezpośrednio niektóre ich rodzaje. Przede wszystkim należy wskazać tu pola bitew (battlefields), które są odrębną kategorią obiektów ujmowanych w rejestrze zabytków przez prowadząca go instytucję Historic England ${ }^{27}$. Aktualnie w rejestrze znajduje się 46 takich pól, a warunkiem ich wpisania było znaczenie historyczne i rozpoznawalność w terenie ${ }^{28}$. Na podobnej zasadzie do innego rejestru wpisuje się nie tylko budowle, ale i miejsca związane $\mathrm{z}$ ważnymi osobami lub ogólnie pojętymi wydarzeniami historycznymi, czyli typowe miejsca pamięci ${ }^{29}$.

Znaczenie historyczne jako podstawowy element tych miejsc pełni szczególnie ważną rolę w prawie ochrony dziedzictwa obowiązującym w USA ${ }^{30}$. Warunki wpisu zabytków (designation) do The National Register of Historic Places określa w nim akt federalny The National Historic Preservation Act z 1966 roku, zgodnie z którym rejestracji podlegają, miedzy innymi, „dystrykty,

26 Skalę zadań tego instytutu określa ogólna statystyka miejsc pamięci narodowej. Według danych z 2006 r., „w Polsce i poza granicami kraju istnieje 50 tysięcy znaków i obiektów pamięci narodowej, w tym m.in. 400 kwater i grobów uczestników powstań narodowych w XIX wieku, prawie 200 cmentarzy, kwater i grobów powstańców wielkopolskich, ponad 1500 obiektów cmentarnych z czasu I wojny światowej oraz 8000 obiektów z okresu II wojny światowej". Kancelaria Sejmu - Biuro Informacyjne - BIULETYN, z posiedzenia: Komisji Kultury i Środków Przekazu (nr 15), Nr 204/V kad., 11.01.2006 r., ISSN 1230-7289, s. 8.

27 Por., National Heritage Act 1983 (1983 c. 47), na podstawie którego Historic England (the Historic Buildings and Monuments Commission for England), an executive non-departmental public body of the British Government sponsored by the Department for Culture, Media and Sport (DCMS), ma obowiązek of, among other things: administering and maintaining the register of England's listed buildings, scheduled monuments, registered battlefields, conservation areas and protected parks and gardens. This is published as an online resource as ,The National Heritage List for England'. https://en.wikipedia.org/wiki/Historic_England (dostęp: 16 marca 2018 r.).

28 Historic England's Register of Historic Battlefields identifies 46 important English battlefields. Its purpose is to offer them protection through the planning system, and to promote a better understanding of their significance and public enjoyment. Battles must have been of clear historical significance, their sites securely established, and these sites to be still recognizable today, if they are to be added to the Register. We call this latter factor topographical integrity.https://historicengland.org.uk/listing/what-is-designation/registered-battlefields/ (dostęp: 16 marca 2018 r.).

29 The Register of Historic Parks and Gardens of special historic interest in England. It provides a listing and classification system for historic parks and gardens similar to that used for listed buildings. The register is also managed by Historic England under the provisions of the National Heritage Act 1983 (section 10 of Schedule 4 to National Heritage Act 1983, provides that: „After Section 8 of the 1953 Act there shall be inserted: 8C Register of Gardens. This section applies where the Commission compile a register of gardens and other lands situated in England and appearing to them to be of special historic interest. (...)". Eligibility for the register is based around documentary research and field survey which attempts to classify and date each park according to set criteria. These are (among other things): sites with an association with significant people or historical events.https:// en.wikipedia.org/wiki/Register_of_Historic_Parks_and_Gardens_of_special_historic_interest_in_England (dostęp: 16 marca 2018 r.).

30 Por., szerzej na ten temat, W. Kowalski: Kwalifikacja wartości zabytku w świetle prawa Stanów Zjednoczonych Ameryki Północnej. Ochrona dziedzictwa kulturowego, nr 2 (16) 2016, str. 79 et seq. 


\section{Zagadnienie ochrony miejsc pamięci w teorii i w praktyce}

miejsca, budowle, struktury, i obiekty posiadające znaczenie dla amerykańskiej historii, (... ${ }^{31}$. $\mathrm{Na}$ poziomie ustawowym kryterium to ma charakter syntetyczny, ale w rezultacie badań i dyskusji w fachowej literaturze amerykańskiej ${ }^{32}$ opracowano szczegółowe wytyczne dla dokonywania oceny konkretnych zabytków w jego świetle, ujęte w akcie wykonawczym do powołanej ustawy jakim są Kryteria Oceny Rejestru Narodowego (National Register Criteria for Evaluation ${ }^{33}$. Jako najważniejsze z punktu widzenia tematu artykułu podać należy dwa wymogi, stanowiące o spełnieniu głównego kryterium znaczenia danego obiektu lub miejsca dla amerykańskiej historii, a mianowicie, są one „związane z wydarzeniami, które dały znaczący wkład do naszej historii” ${ }^{34}$ lub są „związane z życiem znaczących osobistości w naszej przeszłości”35. Przykładem spełnienia pierwszego wymogu jest Sala Forda w Waszyngtonie, gdzie został zastrzelony pierwszy Prezydent USA Abraham Lincoln, a spełnienie drugiego ilustruje pole bitwy Fort Necessity, na którym George Waszyngton stoczył swoją pierwszą bitwę, czy posiadłość Graceland, gdzie mieszkał i tworzył Elvis Presley ${ }^{36}$. Każde z tych miejsc musi spełnić nadto kryterium association, które polega na istnieniu bezpośredniego związku obiektu z wydarzeniem historycznym lub postacią, a zatem jest warunkiem integralności, czyli kompletności jego zachowania w odniesieniu do aspektu historycznego ${ }^{37}$.

Warto dodać, że istnieją również „kryteria wykluczające” (criteria for exclusion) ${ }^{38}$, realizujące zasadę, że nie rejestruje się zwykłych cmentarzy, miejsc urodzenia, grobów postaci historycznych, budowli stanowiących własność instytucji religijnych lub używanych do celów religijnych, obiektów przeniesionych z ich pierwotnej lokalizacji, rekonstrukcji budynków historycznych, obiektów o cechach głównie komemoratywnych, a nadto obiektów, które swoje znaczenie osiągnęły w ciągu ostatnich 50 lat $^{39}$. Od zasady tej można uczynić jednak wyjątek

31 The National Historic Preservation Act of October 15, 1966, 16 U.S.C., str. 470 et seq. Public La 89-665 (October 15 1966), Sec. 101. (a) (1) (A): The Secretary of the Interior is authorized to expand and maintain a National Register of Historic Places composed of districts, sites, buildings, structures, and objects significant in American history, architecture, archaeology, engineering and culture.

32 Por., między innymi, Values and Heritage Conservation. Research Report. The Getty Conservation Institute, Los Angeles 2000.

33 Por., National Register Criteria for Evaluation. Washington, D. C., U.S. Department of the Interior. www. nps.gov/nr/publictions/bulletins/nrb15/nrb15_2.htm.

34 A. That are associated with events that have made a significant contribution to the broad patterns of our history.

35 B. That are associated with the lives of a significant persons in our past.

36 Przykłady podane za N. Tyler, T. J. Ligibel, I. R. Tyler: Historic Preservation. New York, London 2009, str. 136-137.

37 Supra, str. 138.

38 Supra, str. 148.

39 National Register Bulletin. II National Register Criteria for Evaluation. Critera Considerations, str. 1 et seq., Ordinarily cemeteries, birthplaces, graves of historical figures, properties owned by religious institutions or used for religious purposes, structures that have been moved from their original locations, reconstructed historic buildings, properties primarily commemorative in nature, and properties that have achieved significance within the past 50 years (...). 
i wpisać obiekt do National Register, jeżeli, na przykład, miejsce urodzenia lub grób bardzo ważnej postaci historycznej jest jedynym zachowanym miejscem związanym $\mathrm{z}$ tą osobą, cmentarz jako taki jest cenny ze względu na zachowane na nim groby ważnych osób, a także jest istotny ze względu na upływ czasu, cechy stylu lub związek ze zdarzeniami historycznymi, nadto obiekt komemoratywny, który sam w sobie jest cenny ze względu na wiek, projekt lub formę, względnie związek z wydarzeniami w historii ${ }^{40}$.

Kończąc omawianie prawa amerykańskiego należy jeszcze wyjaśnić, że kryterium upamiętnienia wydarzeń oraz osób odgrywa także istotną rolę w wyłanianiu zabytków „wyższej”, narodowej rangi, rejestrowanych w National Historic Landmarks. Wpisuje się tutaj obiekty o szczególnym znaczeniu historycznym ${ }^{41}$, a cechy „podnoszące” znaczenie tych zabytków dla historii Stanów Zjednoczonych wskazane są w rozszerzonych kryteriach ewaluacji. Otóż zgodnie z National Historic Landmark Criteria $a^{42}$, kryterium „znaczenia narodowego" (national significance) spełnią "dystrykty, miejsca, budowle, struktury i obiekty, które posiadają wyjątkową wartość lub jakość dla zobrazowania lub interpretacji dziedzictwa Stanów Zjednoczonych w historii (...), a ponadto: 1 . Są związane $\mathrm{z}$ wydarzeniami, stanowiącymi znaczący wkład i są z nim identyfikowane lub szczególnie prezentują przykłady historii Stanów Zjednoczonych, z których może być czerpane zrozumienie i szacunek dla tych przykładów, 2. Są związane $\mathrm{z}$ życiem osób ważnych dla narodu w historii Stanów Zjednoczonych ${ }^{43}$. Tak sformułowane kryteria stały się podstawą do zakwalifikowania do National Historic Landmarks około 3000 obiektów, stanowiących około 3\% ogólnej liczby 100000 obiektów wpisanych o National Register. Jako typowe obiekty tego rodzaju podaje się w literaturze, na przykład, Mount Vernon, Perl Harbor, Apollo Mission Control Center, the Martin Luter King Jr. Birthplace, a także więzienie na wyspie Alcatraz koło San Francisco ${ }^{44}$.

Jeżeli chodzi o prawo międzynarodowe to należy od razu stwierdzić, że podobnie jak to było w przypadku praw wewnętrznych, dokumenty tego prawa nie zawierają definicji legalnej pojęcia miejsca pamięci narodowej, ani też nie odnoszą się bezpośrednio do tej problematyki. Obejmują jednak te miejsca poprzez oparcie definicji zabytku na kryterium wartości z punktu widzenia historycznego, etnologicznego lub antropologicznego, aczkolwiek zrazu chodziło o zabytki rozumiane, przede wszystkim jako budowle lub inne struktury stworzone

40 C. birthplace or grave of a historical figure of outstanding importance if there is no appropriate site or building associated with his or her productive life; D. A cemetery that derives its primary importance from graves of persons of transcendent importance, from age, from distinctive design features, or form association with historic events. Op. cit. str. 3.

41 Por., szerzej, N. Tyler i inni, str. 151.

42 Por., IX. Summary of the National Historic Landmarks Criteria for Evaluation. National Historic Landmarks Criteria. U.S. Department of the Interior. www.nps.gov/nr/publictions/bulletins/nrb15/nrb15_9.html.

43 1. That are associated with events that have made a significant contribution to, and are identified with, or that outstandingly represent, the broad national patterns of United States history and from which an understanding and appreciation of those patterns may be gained; 2 . That are associated importantly with the lives of persons nationally significant in the history of United States.

44 N. Tyler, str. 150-151. 


\section{Zagadnienie ochrony miejsc pamięci w teorii i w praktyce}

przez człowieka. To pochodzące niewątpliwie z praw krajowych odniesienie widać już w IV konwencji haskiej z 1907 roku, w której mowa jest o obowiązku ochrony zarówno w czasie działań wojennych, jak i okupacji wojskowej "zabytków historycznych" (art. 27 i 56). W nieco rozwiniętej wersji występuje ono także w prawie pół wieku późniejszej konwencji haskiej z 1954 roku, gdzie wskazane są zabytki historyczne, czy to religijne czy to świeckie, które mają znaczenie historyczne (art. 1) ${ }^{45}$.

Wyraźne odróżnienie miejsca od zabytku - budowlinastąpiło dopiero w definicji dziedzictwa zawartej w kolejnym chronologicznie akcie prawa międzynarodowego, to jest w Konwencji UNESCO w sprawie ochrony światowego dziedzictwa kulturalnego i naturalnego z 1972 roku $^{46}$. $\mathrm{Na}$ równi bowiem $\mathrm{z}$ tradycyjnie rozumianymi „zabytkami” ${ }^{47} \mathrm{i}$,zespołami budowli”"48 zaliczono do dziedzictwa jednoznacznie wskazane „miejsca” (sites), to jest „dzieła człowieka lub wspólne dzieła człowieka i przyrody, jak również obszary/tereny, a także stanowiska archeologiczne, mające wyjątkową powszechną wartość $\mathrm{z}$ punktu widzenia historycznego, estetycznego, etnologicznego lub antropologicznego" (art. 1 ust. 3 Konwencji).

Jak się szybko okazało w praktyce, wspomniane rozszerzenie pojęcia dziedzictwa nie otwarło jednak drogi do dalszego dookreślenia prawnego „miejsc pamięci” i wzmacniania ich ochrony, ale nawet stworzyło pewien problem i zahamowało oczekiwany proces. Ma to związek z wprowadzeniem przez Konwencję z 1972 roku nowego, specjalnego instrumentu ochrony dziedzictwa, a mianowicie Listy Dziedzictwa Światowego, która tworzona jest na podstawie kryteriów zawartych w Wytycznych Operacyjnych Stosowania Konwencji (Operational Guidelines for the Implementation of the Convention $)^{49}$. Wspomniane kryteria uszczególowiają definicję konwencyjną i stanowią wytyczne przy rozpatrywaniu obiektów zgłaszanych przez państwa na tę listę $e^{50}$.

Do kwestii nominacji miejsc pamięci odnosi się kryterium VI Wytycznych Operacyjnych, zgodnie z którym wymaga się, aby obiekt lub miejsce "było bezpośrednio lub namacalnie

45 Art. 1: (...) term "cultural property" shall cover movable and immovable property of great importance to the cultural heritage of every people, such as, among other things, monuments of history, whether religious or secular, which are of historical interest (punkt a).

46 Konwencja w sprawie ochrony światowego dziedzictwa kulturalnego i naturalnego, przyjęta 16 listopada 1972 roku, DU 1976, nr 32, poz. 190, załącznik.

47 „.... to jest $i$ : dzieła architektury, dzieła monumentalnej rzeźby i malarstwa, elementy i budowle o charakterze archeologicznym, napisy, groty i zgrupowania tych elementów, mające wyjątkowa powszechna wartość z punktu widzenia historii, sztuki i nauki; (...) (art. 1 ust. 1).

48 (...) oddzielnych lub łącznych, które ze względu na swa architekture jednolitość lub zespolenie z krajobrazem maja wyjątkowa powszechna wartość z punktu widzenia historii, sztuki i nauki; (...) ( art. 1 ust. 2).

49 Operational Guidelines for the Implementation of the World Heritage Convention. WHC.16/01, 20 October 2016.

50 Dalsze wywody oparte są na szerszym artykule autora na ten temat: Miejsca pamięci na tle UNESCO 1972 World Heritage Convention oraz kryterium VI Wytycznych Operacyjnych jej stosowania. W: Ochrona Dziedzictwa Kulturowego, Nr 4, 2017, str. 149-162. 
związane z wydarzeniami lub żywymi tradycjami (...) o wyjątkowej wartości uniwersalnej" ${ }^{1}$. Taka wskazówka sprzyja oczywiście wpisom na listę wszystkich „klasycznych” miejsc pamięci, jeżeli tylko spełniają rzecz jasna kryterium wartości uniwersalnej. Można zatem zapytać, gdzie leży wspomniany wyżej problem, a tym bardziej ewentualne zahamowanie procesu wzmacniania ochrony miejsc pamięci?

Odpowiedź na to pytanie nie leży $\mathrm{w}$ samym sformułowaniu kryterium VI, ani też innych kryteriów zawartych w Wytycznych Operacyjnych, ale w opartej na tym kryterium decyzji Komitetu Dziedzictwa Światowego dotyczącej jednego obiektu - wpisu na listę obozu koncentracyjnego Auschwitz Birkenau. German Nazi Concentration Camp (1940-1945). Już na początku analizy tej decyzji warto wspomnieć, że procedura wpisu obozu wywołała wątpliwości związane $\mathrm{z}$ naturą tego obiektu $\mathrm{w}$ świetle tradycyjnego pojęcia zabytku. W szczególności, chodziło o to, czy mają to być „miejsca”, o wartości zabytkowej łącznie z elementem pamięci jako ich składnikiem niematerialnym, czy też w grę wchodzić mogą „miejsca” całkowicie pozbawione materialnego substratu zabytkowego, a więc także zupełnie "puste", będące jedynie nośnikami pamięci o dokonanych na nich wydarzeniach, na przykład, bitwach, ważnych zjawiskach społecznych itp. Dokonana wcześniej przez autora analiza $10 \mathrm{z} 11$ zabytków wpisanych na Listę Światowego Dziedzictwa w oparciu o kryterium VI wskazuje ${ }^{52}$, iż wszystkie te wpisy zostały dokonane nie tylko $\mathrm{w}$ wyniku spełniania funkcji upamiętniającej, ale także dzięki istnieniu wyraźnego i znaczącego komponentu struktury zabytkowej. Stało się tak mimo wyraźnego sformułowania powołanej wyżej definicji „miejsca” w art. 1 ust. 3 Konwencji, z której wynika, że materialny element zabytkowy nie jest niezbędny dla jego istoty. Dlatego też tkwiąc $\mathrm{w}$ tradycyjnym rozumieniu zabytku i nie zważając na poszerzenie pojęcia dziedzictwa Komitet Dziedzictwa Światowego poszukiwał również w obozie w Auschwitz materialnego elementu zabytkowego. Między innymi, Wiceprzewodniczący Komitetu, M. Parent, skonstatował, że (...) "aczkolwiek baraki tworzące obóz nie mają znaczenia architektonicznego, to jednak tworzą one zespół zgodny z ponurą funkcją, którą wypełniały" ${ }^{33}$.

Warto dodać, że to rozumowanie opierało się na przypadkach wcześniej podanych przez tego autora, na przykład, okolicznościach wpisu na listę miejsca podpisania Deklaracji Niepodległości i Konstytucji USA (Independence Hall, USA), które uzasadniono wartością architektoniczną obiektu oraz jego outstanding historical value, gdyż „wystąpienie tylko jednego z tych aspektów nie byłoby wystarczające do zakwalifikowania zabytku na listę zgodnie

51 (...) „, be directly or tangibly associate with events or living traditions (..) of outstanding universal significance”, Criteria for the assessment of Outstanding Universal Value, pkt II D.

52 Por., W. Kowalski: Miejsca pamięci..., str. 151 et seq.

53 "(...), although the huts which make it up are of no architectural interest (in contrast to Gorée), they do nevertheless form an ensemble which owe its coherence to the sinister function they fulfilled". UNESCO doc: CC79/CONF.003/11, Paris, 11 October 1979, str. 21, raport M. Parenta. 


\section{Zagadnienie ochrony miejsc pamięci w teorii i w praktyce $\square \square^{85}$}

z wymogami konwencji” ${ }^{54}$.

Wspomniana niezgodność dokonywanych przez Komitet ocen konkretnych obiektów $\mathrm{z}$ definicją konwencyjną jest tym bardziej zadziwiająca, że sam autor cytowanych wypowiedzi, M. Parent, po bliższej analizie zapisu tej definicji uznał w tym samym raporcie za co do zasady możliwe zakwalifikowanie do wpisu na listę również sławnych pól bitewnych, które są „pustymi przestrzeniami". Stwierdził bowiem wprost, że sformułowanie art. 1 konwencji w odniesieniu do definicji miejsc, które, jak zauważył, poprzez użycie słów areas including archaeological sites nie ogranicza pojęcia tych areas tylko do terenów zawierających warstwy archeologiczne, ale także obejmuje inne, nie posiadające wyróżniających się elementów architektonicznych ${ }^{55}$.

Ostatecznie zatem nikłość lub zupełny brak substancji zabytkowej o wyjątkowej uniwersalnej wartości architektonicznej nie stanął na przeszkodzie wpisowi obozu Auschwitz na Listę Światowego Dziedzictwa. Niewątpliwie stanowiło to korzystny krok w tworzeniu pojęcia miejsca pamięci, którym może być także teren pozbawiony zabudowy. Podkreślając ten pozytywny fakt trzeba jednak zwrócić uwagę na drugi jeszcze element, w sposób oczywisty znacznie ważniejszy dla ewolucji prawnej ochrony takich miejsc. Otóż bowiem Komitet uporał się wprawdzie $\mathrm{z}$ brakiem komponentu architektonicznego, ale jednocześnie dokonując wpisu obozu Auschwitz na Listę Światowego Dziedzictwa zastosował jednocześnie zabieg uniemożliwiający dokonywanie wpisów miejsc o podobnym charakterze w przyszłości. Polegał on na uznaniu tego obozu za swoisty symbol miejsc tego rodzaju, który ma je reprezentować, co pozwoli uznać wpisywanie na listę dalszych podobnych miejsc za zbędne. Wyjaśnił to w raporcie cytowany już M. Parent pisząc, że wpis ten dokonany został w wyniku szerszej interpretacji terminu „site”, co z jednej strony otwiera drogę do wpisów także znanych pól bitewnych i innych miejsc pozbawionych walorów architektonicznych, ale jednocześnie Auschwitz winien być wpisany jako miejsce symboliczne dla wszystkich ofiar i jako takie pozostać jedynym wpisem tego rodzaju ${ }^{56}$. Wbrew własnej interpretacji definicji „miejsca” autor ten podkreślił dalej, że zasadą winna być także konieczność „ekstremalnej selektywności” przy wyborze miejsc takich jak „sławne bitwy”, gdzie nie ma elementu architektonicznego, a nadto z uporem zalecił potrzebę rozważania, czy rzeczywiście nadają się do wpisu na listę miejsca bez wartości architektonicznej, które były sceną pozytywnych zdarzeń historycznych, wielkich odkryć naukowych bądź

54 "It is, however, worth noting that its listing is justified by its nature as an "architectural work", and by its "outstanding historical value"; one alone of these qualifications would not have been enough for this property to be included in the classification, as laid down by the Convention". UNESCO doc: CC-79/CONF.003/11, Paris, 11 October 1979, Annex, Raport M. Parenta, str. 8.

55 UNESCO doc: CC-79/CONF.003/11, Paris, 11 October 1979, Annex, Raport M. Parenta, str. 8.

56 "(i) on the broader reading of the term "site" areas ... which are of outstanding universal value from the historical...point of view), Auschwitz should undeniably be placed on the List. (...) (iii) Nevertheless, and in order to preserve its symbolic status as monument to all the victims, Auschwitz should, it seems, remain in isolation. In other words, we recommend that it should stand alone among cultural properties as bearing witness to the depth of horror and of suffering, and the height of heroism, and that all other sites of the same nature be symbolized through it". UNESCO doc: CC-79/CONF.003/11, Paris, 11 October 1979, Annex, Raport M. Parenta, str. 21. Por., także treść wpisu: Auschwitz Birkenau. German Nazi Concentration Camp (1940-1945), http://auschwitz. org/n/museum/unesco/. 
legendarnych lub niezwykłych zdarzeńn ${ }^{57}$.

Dla uniknięcia wątpliwości warto jeszcze streścić konkluzje omawianego raportu z 1979 roku, gdzie podsumowano i uzasadniono zreferowane wyżej zasady wpisywania „miejsc” na listę. Stwierdzono w nich, między innymi, że dopuszcza się szeroką interpretację pojęcia sites, która nie wyklucza areas pozbawionych architektury ${ }^{58}$, ale jak podkreślono, zasada ta winna być stosowana restryktywnie w praktyce ${ }^{59}$. Podkreślając podstawową zasadę zależności doniosłości historycznej zabytków, grup zabudowy i miejsc od posiadania przez nie elementu materialnego o oczywistej jakości (tangible features of self-evident quality), wskazano jednocześnie, że w przypadku miejsc reprezentujących pozytywne i negatywne strony historii ludzkości będą one mogły być wpisywane na zasadzie wyjątkowych symboli, każdy jako przykład innych miejsc przypominających podobne wydarzenia ${ }^{60}$. Na tej zasadzie, jak wyjaśniono, „Auschwitz znajdzie się na liście, ale nie będzie precedensem całej serii podobnych miejsc, podczas gdy zabytki i miasta historyczne w sposób nieunikniony stworzą całe „rodziny”. Na listę nie powinno wpisywać się także całych serii sławnych pól bitewnych czy miejsc urodzenia itp., sławnych osób”1.

Przedstawiona wyżej polityka dokonywania wpisu na Listę Światowego dziedzictwa miejsc pamięci musiała od początku budzić kontrowersje, gdyż Komitet na swoich kolejnych posiedzeniach niejednokrotnie szukał dodatkowych argumentów dla jej uzasadnienia. $\mathrm{Na}$ przykład, na posiedzeniu w Helsinkach w 2001 roku podkreślono wyrażoną już w 1979 roku obawę o zbyt dużą liczbę wniosków o wpis na podstawie kryterium VI, obniżającą rzekomo w efekcie znaczenie całej listy jako takiej. Przypomniano także potencjalne polityczne trudności, jakie mogą wyniknąć, na przykład, z motywacji nacjonalistycznej wniosków dotyczących

57 "In any case we would favour an extremely selective approach toward places like "famous battlefields", where there are no architectural features of not within area in question. We must also consider the suitability of certain "places" without architectural merit, which were the scene of a positive historical event, such as a great scientific discovery, or a legendary or fabulous event", j. w., str. 22.

58 "So far as "sites" are concerned, one is inclined to adopt the widest interpretation, which does not exclude "areas" devoid of architecture which are of outstanding interest from the historical, artistic or scientific points of view", j.w. str. 23.

59 „This argument may lead us to a rather broad classification: we should be all the more restrictive in limiting its applicability", j.w., str. 23.

60 „(...) sites representing the positive and negative sides of human history will only be visited with real force if we make the most remarkable into unique symbols, each one standing for the whole series of similar events", j. w. str. 24.

61 "On this principle, Auschwitz would be placed on the List, but would not be a precedent for a whole series of similar sites, whereas monuments or historic towns will inevitably form whole "families". We should also be reluctant to include whole series of famous battlefields or birth places, etc., of great men", j. w., str. 24. 


\section{Zagadnienie ochrony miejsc pamięci w teorii i w praktyce}

wydarzeń historycznych lub znanych osób, co będzie sprzeczne z celami Konwencji ${ }^{62}$. Przy tej okazji zwrócono uwagę na opozycję niektórych państw wobec wpisu na listę Hiroshima Peace Memorial (Genbaku Dome) w 1996 roku. Te i inne argumenty oraz okoliczności, takie jak na przykład, wprowadzenie zasady nominowania na podstawie kryterium VI tylko łącznie z innym kryterium, ograniczające wpisy miejsc na listę ${ }^{63}$, wywołały w końcu pytanie, w jaki sposób takie wpisy dokonywane będą w przyszłości ${ }^{64}$. Nie dało na nie jednoznacznej i stanowczej odpowiedzi specjalne posiedzenie w tej sprawie ekspertów UNESCO w Warszawie w 2012 roku. Podkreślono na nim, między innymi, znaczenie pamięci jako związku kulturowego $\mathrm{z}$ danym miejscem ${ }^{65}$, a nadto, że idee oraz zdarzenia itp., powinny cechować się wyjątkową uniwersalną wartością i winny być związane bezpośrednio z miejscem, które będzie miało podstawowe znaczenie dla zrozumienia tego związku i będzie nominowane do wpisu ( punkt 13, str. 170) ${ }^{66}$. Warto zauważyć, że te uwagi znalazły się tylko w protokole i nie znalazły odzwierciedlenia w przyjętych wówczas rekomendacjach. Zwrócono w nich jedynie uwagę na konieczność dalszego rozwijania zaleceń co do oceny wyjątkowego, uniwersalnego znaczenia ogólnie pojętych idei i zdarzeń oraz ich bezpośredniego związku z miejscem nominowanym do wpisu na podstawie kryterium $\mathrm{VI}^{67}$.

Podsumowując dotychczasowe wywody należy powrócić do postawionego wyżej pytania o problem ochrony miejsc pamięci, a nawet zahamowanie procesu wzmacniania ich ochrony. Otóż jak wskazuje dokonana analiza leży on w wyraźnej tendencji coraz bardziej restryktywnego

62 "Particular attention should be given to cases which fall under criterion (vi) so that the net result would not be a reduction in the value of he List, due to the large potential number of nominations as well as to political difficulties. Nominations concerning, in particular, historical events or famous people could be strongly influenced by nationalism or other particularisms in contradiction with the objectives of the World Heritage Convention". WHC01/CONF.208/INF.13, Paris, 3 December 2001, pkt 10, str. 2. Obawy te spowodowały zmianę kryterium VI w 1994 roku poprzez wykreślenie z niego miejsc związanych z osobistościami, por. K. Piotrowska: Uzasadnienie wpisu na Listę Światowego Dziedzictwa w przeszłości i obecnie. W: B. Szmygin (Red.): Wyjątkowa uniwersalna..., str. 15

63 "This restriction in the application of criterion (vi) makes the inscription of the property solely on the basis of the association with events or living traditions, with ideas (...) impossible". WHC-01/CONF.208/INF.13, Paris, 3 December 2001, pkt 10, str. 3 .

64 "If the application of cultural criterion (vi) is restricted to being used only in conjunction with other cultural or natural criteria, it is not apparent how other outstanding "places of memory" will be inscribed on the World Heritage List in the future." WHC-01/CONF.208/INF.13, Paris, 3 December 2001, str. 10.

65 "...cultural associations that have been recognized include, among others, memory and conscience, ... ". International World Heritage. Expert meeting on Criterion VI, 28-30 March - 2012 Warsaw, Poland, str. 170, pkt 12.

66 "The meeting considered that it was essential for the use of criterion (vi) to demonstrate both that the idea, event etc., was of outstanding universal significance and that it was directly or tangibly linked to the site being nominated..., j. w., str. 170, punkt 13.

67 "C. Recommendations (...). 30 (...). Guidance should cover: (...) b) Assessment of the outstanding universal significance of the ideas/events etc., for criterion (vi); c) Assessing whether the links between the ideas/events etc., of outstanding universal significance and the nominated site are direct o tangible for criterion (vi); d) Definition of conditions of authenticity and integrity for such associations, especially for criterion (vi);..." j. w., str. 173. Warsaw 2012. 
stosowania konwencyjnego pojęcia sites, dążącej do ograniczenia uznania za nie „klasycznych” miejsc pamięci. Przejawia się to $\mathrm{z}$ jednej strony $\mathrm{w}$ negatywnym stosunku do miejsc nie posiadających znaczniejszego komponentu materialnego, z drugiej zaś we wprowadzeniu i praktycznym przestrzeganiu zasady „symbolicznej reprezentacji” danego typu miejsca, którego wpis na Listę Światowego Dziedzictwa ma zastąpić potencjalne wpisanie ewentualnie dalszych takich miejsc.

Czyniąc tę konstatację nie można uciec od stwierdzenia, że stosowanie tych zasad nie znajduje uzasadnienia w tekście Konwencji z 1972, ani też w istocie w samych Wytycznych Operacyjnych. Przyznał to już w 1979 roku cytowany wielokrotnie M. Parent stwierdzając, że dopiero po osiągnięciu przez listę odpowiedniego wyczerpania i reprezentatywności „konkretnych” zabytków możliwe będzie ponowne przemyślenie tej zasady. Niezależnie od wszystkiego będzie to, jak zauważył, bardziej kwestia celowości niż interpretacji litery konwencji ${ }^{68}$.

W tej ostatniej kwestii trudno nie zgodzić się z autorem, który wypowiedział się w cytowanej opinii bardzo oględnie, ale wczytując się w jego wypowiedź można przyjąć, że zdawał sobie sprawę co najmniej z faktu braku podstaw konwencyjnych do przyjęcia przedstawionych zasad. Dotyczy to przy tym obydwu kwestii, to znaczy zarówno braku komponentu materialnego, jak i zasady „symbolicznej reprezentacji”. W cytowanej już definicji „miejsca”, zapisanej w art. 1 ust. 3 Konwencji, mowa jest literalnie o obszarach - miejscach, mających wyjątkową powszechną wartość z punktu widzenia historycznego, estetycznego, etnologicznego lub antropologicznego, a zatem jakikolwiek element dodatkowy, zabytkowy, architektoniczny, czy inny nie jest w ogóle potrzebny. Wszelka zatem interpretacja wprowadzająca taki wymóg jest niewątpliwie zbyt daleko idąca i nie znajduje oparcia w tej definicji. Znacznie surowiej wypada natomiast ocenić drugą z wymienionych zasad, a mianowicie zasadę nazwaną tutaj „symboliczną reprezentacją”. Otóż stosowanie jest działaniem naruszającym Konwencję z 1972 roku, gdyż wprowadza ograniczenie wpisów nie znajdujące w niej żadnej podstawy. Z takiego z pewnością powodu wprowadzona została nie, na przykład, do Wytycznych Operacyjnych, a przyjętą ją w konkretnej decyzji Komitetu Dziedzictwa dotyczącej wpisu obozu Auschwitz na listę.

Wyjaśniając tę ocenę należy z całą mocą podkreślić, że zgodnie z art. 11 ust. 5 Konwencji Komitet ma pełne prawo ustalania kryteriów, na podstawie których dokonuje wpisów na listę ${ }^{69}$. Jeżeli jednak można zrozumieć, a nawet poprzeć wspomniane wyżej zabieg o takie formułowanie i interpretowania kryteriów, aby uchronić listę przed nadmiernym upolitycznieniem, czy utratą rzeczywistego znaczenia, o tyle wprowadzenie zasady „symbolicznej reprezentacji” nie da się w żaden sposób pogodzić $\mathrm{z}$ art. 1 Konwencji. Jak już wyjaśniono wyżej, przepis ten daje jednoznaczną podstawę do dokonywania wpisów miejsc pamięci na listę i nie przewiduje

68 "In our opinion, only when the List has achieved a degree of consistency, and can claim to be representative of "concrete" cultural property, will it be possible to reconsider this principle, which is, after all, more a matter of expediency than of statutory interpretation of the Convention", j. w., str. 24.

69 Art. 11 ust. 5: The Committee shall define the criteria on the basis of which a property belonging to the cultural or nature heritage my be included in either of the lists mentioned above in paragraphs 2 and 4 of this article". 


\section{Zagadnienie ochrony miejsc pamięci w teorii i w praktyce}

jakichkolwiek ograniczeń bądź wyjątków. Nie jest zatem możliwe wykluczenie możliwości wpisu całej kategorii miejsc pamięci jedynie na podstawie decyzji Komitetu Dziedzictwa, gdyż nie ma on do tego wystarczającej podstawy prawnej, tym bardziej jeżeli skutkiem tej decyzji jest $\mathrm{w}$ istocie zmiana art. 1 Konwencji. Czym innym jest wszak uprawniona interpretacja jej norm, $w$ tym poprzez ustanowienie kryteriów ich stosowania, a czym innym ograniczenie przedmiotowe możliwości dokonywania wpisów sites. Nie wymaga przecież wyjaśniania, że wspomniany artykuł ma charakter podstawowy dla całej konstrukcji ochrony światowego dziedzictwa kulturowego, a zmienić go jako normę konwencyjną mogą jedynie państwa strony konwencji na drodze jej nowelizacji. Każde działanie wywołujące taki skutek inną drogą musi być uznane jako działanie contra legem. W świetle powyższego trudno wytłumaczyć, na jakiej podstawie, wobec jasnego sformułowania art. 1 konwencji i kryterium VI, zasada „symbolicznej reprezentacji”, wprowadzona w decyzji o konkretnym wpisie może być uznawana za wiążącą dla następnych wpisów. Na tym też polega główny problem stosowania Konwencji z 1972 roku $\mathrm{w}$ teorii i praktyce.

W konkluzji wypada stwierdzić, że aktualny stan regulacji ochrony prawnej miejsc pamięci jak i praktyki nie jest zadawalający. Dotyczy to zarówno regulacji na poziomie krajowym, gdzie poza nielicznymi wyjątkami ochronę miejsc trzeba „wyinterpretowywać” z przepisów ogólnych ochrony zabytków, jak i na niwie międzynarodowej, której podstawowy dokument dotykający tej materii, Konwencja z 1972 roku, daje wprawdzie podstawę do wpisu takich miejsc na Listę Światowego Dziedzictwa, ale w praktyce jej stosowania Komitet Dziedzictwa ograniczył możliwość ich dokonywania. W przypadku miejsc zagłady ograniczenie to poprzez wprowadzenie kryterium „symbolicznej reprezentacji” takich miejsc nosi cechy działania bez podstawy prawnej i narusza art. 1 konwencji. W konsekwencji, dalszym skutkiem tej decyzji jest wyhamowanie procesu rozwoju ochrony prawnej miejsc pamięci ${ }^{7^{0}}$.

70 Należy w tym miejscu zauważyć, że podstawą ochrony takich miejsc nie może być, na przykład, Convention for the Safeguarding of the Intangible Cultural Heritage. Paris, 17 October 2003. Doc. MISC/2003/CLT/CH/14, czy European Convention on the protection of the archaeological heritage, Valetta 1992, por., szerzej na ten temat W. Kowalski: Miejsca pamięci..., str. 160 et seq. 